\title{
Sustainable Development and Transhumanism - Enlightenment Visions of Future Generations
}

\author{
Zrównoważony rozwój a transhumanizm \\ - oświeceniowe wizje przyszłych pokoleń
}

\author{
Jacek Leszek Łapiński*, Łukasz Sadłocha**
}

\author{
*The John Paul II Catholic University of Lublin, Poland \\ E-mail: jalap@kul.lublin.pl, ORCID:0000-0001-9475-3377 \\ ** College of Business and Entrepreneurship in Ostrowiec Swietokrzyski, Poland \\ E-mail: lusad.lusad@gmail.com,ORCID:0000-0001-8093-3289
}

\begin{abstract}
Both sustainable development and transhumanism are based on forecasting, meaning making judgments about what the future will be like, and they are made according to the results of scientific research.

Sustainable development is an already implemented concept, yet transhumanism is still far from a similar degree of implementation. However, it is worth reflecting on their coexistence, as they already have their place in the scientific discourse. The element connecting sustainable development with transhumanism seems to be an enlightenment vision of human development. The aim of the article is to show the similarities and differences in these approaches to future generations.
\end{abstract}

Key words: sustainable development, transhumanism, enlightenment, future generations

\section{Streszczenie}

Zarówno zrównoważony rozwój, jak i transhumanizm bazują na prognozowaniu, czyli na sądach odnoszących się do przyszłości, sformułowanych pod wpływem wyników pozyskanych z badań naukowych.

Zrównoważony rozwój jest koncepcją już realizowaną, a do podobnego stopnia realizacji daleko jeszcze transhumanizmowi. Warto jednak podjąć refleksję nad ich koegzystencją, gdyż posiadają już swoje miejsce w dyskursie naukowym. Elementem łączącym zrównoważony rozwój z transhumanizmem wydaje się być oświeceniowa wizja rozwoju ludzkości. Celem artykułu jest pokazanie podobieństw i różnic w ich podejściu do przyszłych pokoleń.

Słowa kluczowe: zrównoważony rozwój, transhumanizm, oświecenie, przyszłe pokolenia

\section{Introduction}

Predicting the future, or rather being able to accurately assess what might happen, is a characteristic trait of all people living in every historical period. Initially, it was not very rational, mostly intuitive, and commonsensical at best. It had a very low degree of certainty. Currently, attempts to predict the future are becoming more and more rational; they are not only based on common sense, but direct scientific observations (Rolbiecki, 1970; Becht and Filipkowski, 2018). This way of predicting the future by using strictly rational, scientific methods can be defined as forecasting. It allows us to formulate fairly objective judgments about the possible sequence of future events, processes, trends, etc. These judgments remain uncertain but verifiable, and therefore largely acceptable.

Forecasts provide information about a studied phenomenon (informational function), presenting the premises leading to rational decisions (preparatory function) and then stimulate the realization of a favorable forecast or counteracting an unfavorable one (activating function). In the light of the above, it 
should be emphasized that the concepts of sustainable development (hereinafter abbreviated SD) and transhumanism (abbreviated $\mathrm{H}+$ ) also apply to the human future. While SD is the implementation of previous forecasts, $\mathrm{H}+$ provides new information about the future of humanity, and this has already found its place in the scientific discourse, now quite difficult to ignore. Therefore, it is worth reflecting on the possible confrontation between SD and $\mathrm{H}+$, at least in the context of the approach to future generations of people, namely their future condition, development opportunities, or even conditions for surviving. The mentioned type of reflection will be the main goal of the publication.

\section{A general outline of SD and $\mathrm{H}+$}

The Encyclopedia Britannica provides the following definition of SD by Federico Cheever and Celia Campbell-Mohn: Sustainable development is an approach to economic planning that attempts to foster economic growth while preserving the quality of the environment for future generations (Cheever F., Campbell-Mohn C. I., 2002). It should be noted, however, that the first and most general definition of SD was developed by the World Commission for Environment and Development summoned by Gro Harlem Brundtland. In the opinion of the same Commission: sustainable development is development that meets the needs of the present without compromising the ability of future generations to meet their own needs (Brundtland, 1983, p. 41). According to Monika Stanna and Adam Czarnecki (2011, p. 15), this definition emphasized the concept of intergenerational justice and the ability to forward intergenerational thinking. The main emphasis was placed on the permanent intergenerational dimension of meeting people's needs. Such issues as, for example, socio-economic development or environmental protection appeared later.

Ewa Rokicka and Wojciech Woźniak (2016, p. 98123) illustrate the multitude of existing definitions of SD. These authors distinguished, inter alia, official international definitions emphasizing the goals of $\mathrm{SD}$, definitions focusing on indicators measuring $\mathrm{SD}$, definitions referring to the basic values of SD and definitions referring to practicing SD. Therefore, taking into account all the above-mentioned definitions, it should be concluded that SD consists in seeking a compromise between social, economic and ecological reasons for keeping in mind the future generations of people. Moreover, the problem of the lack of one definitive, an unambiguous definition of $\mathrm{SD}$, is closely related to the multidimensional issue of SD, since it takes into account, for example, the spatial, institutional, and even moral dimensions, and additionally tries to place all this into an intergenerational perspective.

In the case of $\mathrm{H}+$, the Encyclopedia Britannica presents the following definition by Sean Hays: Trans- humanism, social and philosophical movement devoted to promoting the research and development of robust human-enhancement technologies (Hays, 2014). In turn, Max More, a leading transhumanist, formulated a definition of $\mathrm{H}+$ accepted by almost all environments related to $\mathrm{H}+$ and available on the official $\mathrm{H}+$ website. In his opinion, Transhumanism is a class of philosophies of life that seek the continuation and acceleration of the evolution of intelligent life beyond its currently human form and human limitations by means of science and technology, guided by life-promoting principles and values (More, 1990).

$\mathrm{H}+$, as the movement's official website reports, analyzes the dynamic interaction between humanity and the acceleration of technology. It uses an interdisciplinary approach to do so, aiming to ethically use currently available and other hypothetical technologies. The interests of $\mathrm{H}+$ focus, for example, on both human and posthuman topics, issues related to singularity, the risk of extinction and mind transfer, whole brain emulation, substrate-independent minds, etc. (More, 2013). As in the case of SD, also in relation to $\mathrm{H}+$ one can speak of a multitude of definitions. Generally speaking, $\mathrm{H}+$ looks for common elements located in the process of human development and in the accelerating development of technology, taking into account the various social, economic and environmental implications (Bardziński, 2015; Rutkowska, 2017).

\section{Similarities and differences in the approach to fu- ture generations}

Taking into account the above approaches to SD and $\mathrm{H}+$ and the remarks concerning them, one can notice significant similarities and differences between them. Both $\mathrm{SD}$ and $\mathrm{H}+$ relate to future generations and take into account various issues, such as economic, ecological, etc. Both orientations are, therefore, characterized by an interdisciplinary approach. More precisely, SD focuses on achieving stability in meeting human needs, while $\mathrm{H}+$ focuses on achieving stable human enhancement technology.

The difference between SD and $\mathrm{H}+$ revealed above is most likely already present in the inspirations that the representatives of SD and H+ draw from the Enlightenment era. John Harlow (2011) mentions Francis Bacon, Adam Smith and Jean-Jacques Rousseau among the precursors of SD. The views expressed by these authors meant that, according to Andrzej Papuziński (2017, p. 310), SD drew the following theses from the Enlightenment: (1) recognizing global problems as social problems that begin with the problems of individual people, (2) the belief that all social problems are solvable as problems born within social practice, (3) the concept of the possibility of solving global problems in a political way. Nick Bostrom (2005, p. 2-4) indicated that the precursors to $\mathrm{H}+$ include Francis Bacon, Isaac Newton, 
Thomas Hobbes, John Locke, Immanuel Kant, Nicolas de Condorcet, Julien de la Mettri, Benjamin Franklin and Friedrich Nietzsche. According to Bostrom, the work of these researchers meant that $\mathrm{H}+$ adopted the Enlightenment conviction of humanism: (1) concerning humanity's continuous improvement (2) with the use of technology (reason).

In terms of generations, SD focuses on solving problems that developing humanity must face. $\mathrm{H}+$ presents new perspectives for future generations related to the development of technology. Thus, it can be argued that the problem of SD seems to be wider and somehow includes the issues related with $\mathrm{H}+$. The source of differences seems to be the following. Lech Gawor (2007, p. 25) points out that in SD, human rationality is related to the degree of coexistence of the human world with the world of nature.

A destructive economy using natural goods worsens the quality of human life. Therefore, taking into account the development of civilization, one should include values, human needs and the possibility of satisfying them, keeping in mind that there are limited natural resources. This approach also takes into account technological development as presented by Zbigniew Hull (2007, p. 50), one of the three main threats to humanity undertaken by SD. The time needed to become aware of the effects of new technologies is longer than the timeline of their implementation, and sometimes their effects are not even analyzed at all. New technologies are being introduced into ecosystems and incorporated into biogeochemical cycles. In addition, worth mentioning here is the World Report (Rashid et al., 2018) issued by the United Nations Economic and Social Council devoted to pioneering technologies that herald hope for humanity.

The difference between SD and $\mathrm{H}+$ is also visible in the concepts of the changeability vs. stability of human nature present during the Enlightenment era, as assumed by $\mathrm{SD}$ and $\mathrm{H}+$. Sławomir Raube mentions the sources of this dichotomy in the Enlightenment (2015, p. 23, 25). In his opinion, during the Enlightenment, ideas for reforming the world were sought primarily in man. On the one hand, thinkers such as Voltaire, Montesquieu or Diderot mostly emphasized the primacy of reason. From the point of view of reason, man naturally possessed some extremely important equipment, meaning laws that had to be explored. On the other hand, David Hume, Adam Smith, Francis Hutcheson, Adam Ferguson and others diminished the importance of reason, emphasizing feelings.

It is difficult to find any permanent natural disposition in man in this kind of orientation; man is who he is at the present moment. In view of the above distinction presented by Raube, both SD and H+ emphasize the idea of human development through reason, and this develops man's world. Yet, SD seems to accept the stability of human nature, whereas $\mathrm{H}+$ states the opposite: human nature is changeable in its foundations, thus susceptible to change, and should be changed by technology. This conclusion can be reached by looking at both previous and current publications on SD and $\mathrm{H}+$. In the case of SD, it is difficult to find publications reflecting on human nature, while many publications on $\mathrm{H}+$ include it (Hołub, 2015). Moreover, Bostrom (2005, p. 2-4) emphasizes that $\mathrm{H}+$ shares the Enlightenment belief about humanism and man's continuous improvement through the use of technology, even to the extent that it allows radically changing human nature.

Taking into account the aforementioned differences between $\mathrm{SD}$ and $\mathrm{H}+$, it should come as no surprise that these orientations differ in their approach to future generations. At this point, worth highlighting are Edith Brown Weiss' thoughts (1992, p. 22-23) on honesty towards future generations. The author has distinguished three normative principles of intergenerational equality. The first is the principle of maintaining the freedom to choose development options, presupposing the need to protect the diversity of the natural and cultural resource base in such a way that each generation does not excessively limit the possibilities of solving problems and satisfying the personal values of future generations. The second is the principle of maintaining quality, according to which each generation should hand over the planet in a state no worse than the condition in which it was received, because maintaining diversity does not necessarily mean maintaining quality. The third point is the principle of protecting access to available resources. It should be flexible enough for the next generation to achieve their goals according to their value system. There is no doubt that in SD, a generation is understood as humanity living in a similar period and having specific values, and therefore analyzed from a demographic and economic perspective. $\mathrm{In} \mathrm{H}+$, the above perspectives are also taken into account, but limited in time, only until a human being is understood as information unions present on the medium of a human body in the basic version (body version 1.0) or partially improved (body version 2.0). This perspective changes if you have a convertible body (body version 3.0).

Grzegorz Hołub (2015, p. 87-93) draws attention to the problems related to the concept of the human person understood in this way, a person having an interchangeable body as presented by Raymond Kurzweil. One of the main problems seems to be the issue of the principle of what constitutes a person, what it means to deal with a person. The fact is that naturalists do not accept the existence of a constitutive principle that is qualitatively superior, supernatural. For naturalists, the constitutive principle is related to the collocation or combination of natural (biological, psychological, social, cultural, etc.) elements that make up a person.

Unfortunately, according to Kurzweil, in the near future, this part will be able to be modified and processed, so such patterns cannot comprise a principle 
constituting a person. Another problem mentioned by Hołub is the question of the identity of the person recorded on a new (e.g. extra-biological, electronic) medium. Kurzweil himself points out that such a person is not the same. The copy merely personifies the copied human person. Also, the inner world of the copied person will be different because the medium is different. The problems presented by Hołub lead to further issues. The creation of a new person will not be related with the biological growth of their body. This will force us to draw a new borderline between one generation and the next, and perhaps even redefine the concept of a generation. It will also be difficult to define common values that will guide a given generation in their development.

\section{Final remarks}

It is possible that SD and $\mathrm{H}+$ will have to coexist with each other. SD already exists and, as an idea or program of action, has entered into many areas of human life. It has become the subject of academic research and university analyses. SD has found its place in legislation, government policy, as well as social and local government projects. In turn, the entire $\mathrm{H}+$ philosophical worldview, along with its political and social movement, is now centralized around the Humanity + organization. It has offices around the world, an official website, an internet magazine, and organizes meetings and conferences. $\mathrm{H}+$ is also present in politics. In the USA, it is promoted by such political parties as the U.S. Transhumanist Party and in the UK the Transhumanist Party as well. It is also known in Russia (Sykulski, 2013). A narrow group of respondents who participated in Anna Czajkowska's research $(2018$, p. 182) is convinced of the mentioned coexistence of SD and $\mathrm{H}+$. People who have some knowledge about $\mathrm{H}+$ see potential in this concept and a chance for humanity. However, they emphasized the need to take into account SD as a kind of guarantor of creating conditions that will not endanger human life. Such integration is also being considered by Vyacheslav Mantatov and Vitaly Tutubalin (2018, p. 722-723). According to them, this integration, even in the event of technological singularity, can become an existential opportunity for human existence if we look at man's development from a cosmocentric perspective.

Under the new environmental conditions, technical measures will enable unlimited expansion of consciousness, strengthening one's cognitive abilities and human bodily parameters. This will allow humanity to develop in an unlimited and sustainable way. The problem is that, according to Michał Klichowski (2014, p. 145), technologically improving a human being (cyborgization) means preferring efficiency, standardization and homogeneity instead of individuality, diversity and otherness. In other words, striving to attain the status of a post-human being means striving towards an identical being, so it is de facto dehumanized, deindividualized. It is a journey towards a world of perfect clones, a neutralized, universal world that can be called an identity hell.

In conclusion, despite differences in the approaches to understanding future generations, integrating SD and $\mathrm{H}+$ is possible. Raymond Kurzweil presented an extreme $\mathrm{H}+$ position, unfortunately most often quoted in scientific studies. However, one should also take into account moderate transhumanists who do not want to free man from his corporeality nor make him immortal, but only extend his biological life as long as possible. Following the division presented by Marcin Garbowski (2015, p. 35-36), such $\mathrm{H}+$ trends as technogaianism or immortalism are worth taking into consideration. Technogaianism is a combination of transhumanism and ecology. It calls for using non-invasive technology to restore the natural ecosystem and bring about the harmonious coexistence of humans and the natural environment. Technological progress is the main factor that will allow people to responsibly use natural resources and stop environmental destruction. Immortalism, in turn, is a trend that promotes the idea of radically extending human life through the use of genetic engineering, stem cells and nanotechnology. Key figures in this orientation are biogerontologists Aubrey de Gray and Marios Kyriazis.

It should be noted at this point that the immortalist approach to future generations of humans, people with only partially perfected bodies, agrees with the approach proposed by SD, as it only extends the duration of a generation. On the other hand, in the case of generations that can exchange bodies, important questions and doubts arise regarding this immortalistic orientation. Some of them are worth pointing out. For example, as the evolutionary basis of consciousness, meaning the biological body, becomes irrelevant, should the environment from which it evolved be cared for? Besides, how are we to distinguish in an information system between a consciousness uploaded from a biological human and a consciousness created artificially?

Wouldn't it be better to generate awareness programs right now, thus creating future generations of new people, instead of working on new vehicles for those born biologically? How are we to think about the next generations of people, since in current evolutionary computer programs, entire generations of objects pass us by in a second? In the light of the above remarks, it seems reasonable for Klichowski (2014, p. 145-147) to state that the real technical and technological possibilities of improving both an individual person and entire future generations does not mean the necessity to implement them. Not everything that is possible is worth pursuing. The price that can be pre-estimated now, and that humanity will have to pay in the future, may turn out to be simply too high. 


\section{References}

1. BARDZINSKI F., 2015, Posthuman - Postnature? Transhumanism and Environmental Ethics, Studies in Global Ethics and Global Education, 4: 18-33.

2. BECHT L., FILIPKOWSKI P., 2018, Ćwiczenie wyobraźni socjologicznej - polska futurologia naukowa lat 70. XX wieku, Stan Rzeczy, 1(14): 41-69.

3. BOSTROM N., 2005, A History Of Transhumanist Thought, Journal of Evolution and Technology, 14(1): 1-25.

4. BRUNDTLAND G. H., 1987, Our Common Future, World Commission on Environment and Development, Oslo.

5. CHEEVER F., CAMPBELL-MOHN C. I., 2002, Environmental law, www.britannica.com/topic/environmental-law/Sustainable-development (19.03.2021).

6. CZAJKOWSKA A., 2018, Transhumanizm - przyszłość czy zagłada naszej cywilizacji?/Transhumanism - future or destruction of our civilization?, $\mathrm{Za}$ rzadzanie mediami/ Media Management, 6(2): 173183.

7. GRABOWSKI M., 2015, Transhumanizm. Geneza założenia - krytyka/ Transhumanism: Origins - Fundamentals - Critique, Ethos, 28(3): 23-41.

8. GAWOR L., 2007, Idea zrównoważonego rozwoju w kontekście historiozoficznym/Sustainable development in the context of our philosophy of history, Problemy ekorozwoju/ Problems of Sustainable Development, 2(2): 19-25.

9. HARLOW J., 2011, A Review of Utopian Themes in Sustainable Development Discourse, Sustainable Development, 21(4): 270-280.

10. HAYS S. A., 2014, Transhumanism, www.britannica.com/topic/transhumanism (19.03.2021).

11. HOLUB G., 2015, Transhumanizm a koncepcja osoby/Transhumanism and the concept of the person, Ethos, 28(3): 83-94.

12. HULL Z., 2007, Czy idea sustainable development ukazuje nową wizję rozwoju cywilizacyjnego?/ Does the idea of the sustainable development show a new vision of the development of the civilization?, Problemy Ekorozwoju/ Problems of Sustainable Development, 2(1): 49-57.

13. Humanity+, 2019, Philosophy, humanityplus.org/ philosophy/ (22.06.2019).
14. KLICHOWSKI M., 2014, Narodziny cyborgizacji. Nowa eugenika, transhumanizm i zmierzch edukacji, Wydawnictwo Naukowe UAM, Poznań.

15. MANTATOV V., TUTUBALIN V., 2018, Sustainable Development, Technological Singularity and Ethics, European Research Studies Journal, 21(4): 714725.

16. MORE M., 1990, Transhumanism. Towards a Futurist Philosophy, web.archive.org/web/200510291251 53/http://www.maxmore.com/transhum.htm (19.03.2021)

17. MORE M., 2013, The Philosophy of Transhumanism, humanityplus.org/transhumanism/philosophy-oftranshumanism/ (19.03.2021)

18. PAPUZINSKI A., 2017, Filozoficzne dziedzictwo oświecenia a zrównoważony rozwój/The philosophical legacy of the enlightenment and sustainable development, Zeszyty Naukowe Politechniki Ślaskiej, Seria: Organizacja i Zarzadzanie/ Scientific Papers of Silesian University of Technology. Organization and Management Series, 112: 309-320.

19. RASHID H., CHENG H. W. J., HUNT N. (eds.), 2018, World Economic And Social Survey 2018: Frontier Technologies For Sustainable Development, United Nations.

20. RAUBE S., 2015, Oświeceniowa koncepcja człowieka: filozoficzna reforma antropologii politycznej, Elpis, 7(11-12): 15-25.

21. ROKICKA E., Woźniak W., 2016, W kierunku zrównoważonego rozwoju: koncepcje, interpretacje, konteksty, Uniwersytet Łódzki, Łódź.

22. ROLBIECKI W., 1970, Przewidywanie przyszłości. Elementy prognozologii, Wiedza Powszechna, Warszawa.

23. RUTKOWSKA A., 2017, Aksjologiczno-ekonomiczne implikacje transhumanizmu, Kultura $i$ Wartości/Culture and Values, 22: 149-176.

24. STANNY M., CZARNECKI A., 2011, Zrównoważony rozwój obszarów wiejskich Zielonych Ptuc Polski: próba analizy empirycznej, Instytut Rozwoju Wsi i Rolnictwa PAN, Warszawa.

25. SYKULSKI L., 2013, Rosyjski transhumanizm - geneza i współczesność, Ante Portas - Studia nad Bezpieczeństwem/Ante Portas - Security Studies, 2:89101.

26. WEISS E. B., 1992, In Fairness To Future Generations and Sustainable Development, American University International Law Review, 8(1): 19-26. 